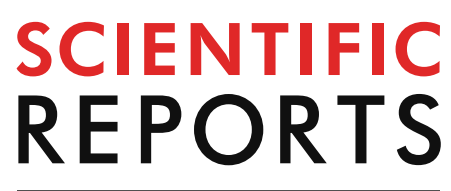

natureresearch

Check for updates

\title{
Removal of anionic dye Congo red from aqueous environment using polyvinyl alcohol/sodium alginate/ ZSM-5 zeolite membrane
}

\author{
Sabarish Radoor ${ }^{1 凶}$, Jasila Karayil ${ }^{2}$, Jyotishkumar Parameswaranpillai ${ }^{1}$ \& \\ Suchart Siengchin ${ }^{1 凶}$
}

In this study, a novel PVA/SA/ZSM-5 zeolite membrane with good regeneration capacity was successfully prepared by solvent casting technique. The properties of the membranes were assessed by employing different characterization techniques such as X-ray diffraction (XRD), Fourier-transform infrared spectroscopy (FT-IR), scanning electron microscope (SEM), optical microscopy (OP), thermogravimetric analysis (TGA), contact angle and universal testing machine (UTM). XRD, TGA and UTM results revealed that the crystallinity and thermo-mechanical performance of the membrane could be tuned with zeolite content. The successful incorporation of zeolite into the polymer matrix was confirmed by FT-IR, SEM and OP analysis. The adsorption ability of the as-prepared membrane was evaluated with a model anionic dye, Congo red. Adsorption studies show that the removal efficiency of the membrane could be tuned by varying zeolite content, initial concentration of dye, contact time, $\mathrm{pH}$ and temperature. Maximum dye adsorption $(5.33 \mathrm{mg} / \mathrm{g})$ was observed for $2.5 \mathrm{wt} \%$ zeolite loaded membrane, at an initial dye concentration of $10 \mathrm{ppm}, \mathrm{pH} 3$ and temperature $30^{\circ} \mathrm{C}$. The antibacterial efficiency of the membrane against gram-positive (Staphylococcus aureus) and gram-negative bacteria (Escherichia coli) was also reported. The results show that membrane inhibits the growth of both gram-positive and gram-negative bacteria. The adsorption isotherm was studied using two models: Langmuir and Freundlich isotherm. The results show that the experimental data fitted well with Freundlich isotherm with a high correlation coefficient $\left(R^{2}=0.998\right)$. Meanwhile, the kinetic studies demonstrate that pseudo-second-order $\left(R^{2}=0.999\right)$ model describe the adsorption of Congo red onto PVA/SA/ZSM- 5 zeolite membrane better than pseudo-first-order $\left(R^{2}=0.972\right)$ and intra particle diffusion model $\left(R^{2}=0.91\right)$. The experimental studies thus suggest that PVA/SA/ZSM- 5 zeolite could be a promising candidate for the removal of Congo red from aqueous solution.

Majority of industries dumped untreated water directly into water bodies, thus contaminating it with toxic metals, dyes, pesticides and insecticides ${ }^{1-3}$. The severity of water pollution is scaling up steadily thus making it one of the major issues to be solved by the urban world. Water pollution is not only a threat to the environment but it also adversely affects humans and aquatic species ${ }^{4,5}$ It is estimated that $17-20 \%$ of industrial water pollution comes from dyeing industries ${ }^{6}$. Azo dye is the main class of synthetic dye which represents about $90 \%$ of all organic colorant ${ }^{7}$. Congo red (CR) is one of the best examples for azo dye and is chemically known as sodium salt of 3 , 3'-([1,1'-biphenyl]-4,4'-diyl) bis (4-aminonaphthalene-1-sulfonic acid $)^{8}$. It is widely used in wood, pigment, textile, dyeing, plastic and printing industries ${ }^{9-13}$. It is toxic in nature and pose a threat to both humans and animals. It causes several health issues in humans such as anorexia, weakness and gastrointestinal irritation ${ }^{14,15}$. As it is a benzidine based dye, it is suspected to have carcinogenic and mutagenic property ${ }^{16,17}$. Congo red enters into the water bodies through several industrial effluents. Owing to its high structural stability, it is quite resistant

\footnotetext{
${ }^{1}$ Department of Mechanical and Process Engineering, The Sirindhorn International Thai-German Graduate School of Engineering (TGGS), King Mongkut's University of Technology North Bangkok, 1518 Wongsawang Road, Bangsue, Bangkok 10800, Thailand. 'overnment Women's Polytechnic College, Calicut, Kerala, India. ${ }^{\square}$ email: sabarishchem@gmail.com; suchart.s.pe@tggs-bangkok.org
} 
towards biodegradation and thus Congo red persist as contaminant in water environment for a long period of time. In this context, it is worthwhile to find a suitable adsorbent for the removal of Congo red from water ${ }^{18}$.

Water quality could be improved by various treatment methods such as flocculation, ion exchange, ozonation and adsorption ${ }^{19-22}$. Adsorption technique is one of the frequently adapted methods to improve the quality of water $^{23-25}$. The interest in this technique comes from its ecofriendly and cost-effective nature, availability of wide range of adsorbent, simple experimental setup and regeneration of adsorbent ${ }^{26}$. Synthetic adsorbent exhibits high efficiency for the removal of toxic metals and dyes from aqueous medium. Therefore, it has been widely used to improve the quality of polluted water ${ }^{27,28}$. However, most of the synthetic adsorbents are toxic in nature and causes environmental pollution. Thus in recent years, there is great scientific interest in employing natural adsorbents such as clay, zeolite, date stones, rice husk and orange peel for dye removal studies ${ }^{29-33}$.

Polymers and polymer composites have been successfully used as adsorbent for water purification purpose. The properties such as good stability, reusability and selectivity, make them one of the promising candidates for water treatment purpose ${ }^{34-36}$. Ample reports are available in literature regarding the use of polymer composite membranes for removing textile dyes from water ${ }^{37-39}$. For instance, Mahmoodi et al. ${ }^{40}$ developed PVA-chitosan nanofiber and reported its ability to remove anionic dye such as Direct Red and Reactive Red from water. Recently, Hu and coworker ${ }^{41}$ developed tannic acid/PVA/sodium alginate hydrogel bead which exhibit excellent adsorption power (adsorption capacity: $147.06 \mathrm{mg} / \mathrm{g}$ ) for methylene blue. Kloster et al. ${ }^{42}$ reported that chitosan/ iron oxide films could be a potential adsorbent for Congo red and possess sorption capacity of $700 \mathrm{mg} / \mathrm{g}$. Kalantari et al. ${ }^{42}$ investigated the dye adsorption ability of chitosan/polyvinyl alcohol/talc composite and reported that the prepared composite displayed good adsorption efficiency for Congo red as well as methyl orange. Similarly, Habiba et al ${ }^{43}$ successfully employed electro spun chitosan/polyvinyl alcohol/ $/ \mathrm{TiO}_{2}$ nanofiber for the removal of Congo red and methyl orange from water. Zhao et al. ${ }^{44}$ proposed kaolin/calcium alginate membrane as a suitable adsorbent for the removal of toxic dye (brilliant blue G250, Congo red, and methylene blue). The membrane exhibits removal rate of $100 \%, 95.22 \%$, and $62.86 \%$, respectively for brilliant blue G250, Congo red, and methylene blue. Zhang et al. ${ }^{45}$ developed a novel chitosan/alginate sponge using freeze dry method and employed it for the removal of Congo red from aqueous medium. Based on the experimental result they report that $0.1 \mathrm{~g}$ of adsorbent has high removal efficiency (98.97\%) for Congo red.

Zeolite is a naturally occurring aluminosilicate with wide range of application ranging from catalysis to water purification ${ }^{46,47}$. High surface area along with porous nature is responsible for its remarkable adsorption power $^{48,49}$. The porosity of zeolite could be modified by several techniques such as templating method, dealumination, desilication etc. ${ }^{50-52}$. Zeolite containing both micro and mesopores are termed as hierarchical zeolites and are superior to conventional zeolite. Zeolites based polymer composites have been successfully employed for the removal of toxic contaminants from water ${ }^{53,54}$. However, there is no report on the usage of hierarchical zeolitebased polymer composite for the removal of Congo red from water. So, we thought it worthwhile to synthesis a hierarchical zeolite and employed it to fabricate an ecofriendly polymer membrane for Congo red removal. The polymer we choose for the current work is polyvinyl alcohol (PVA) and sodium alginate (SA), which are both ecofriendly and biocompatible in nature. The dye adsorption efficacy of the prepared membrane in terms of various experimental conditions such as zeolite loading, initial dye concentration, contact time, $\mathrm{pH}$ and temperature was investigated. The antibacterial activity and the reusability of the prepared membrane is also presented. The adsorption isotherm and kinetics of Congo red adsorption onto the membrane is also highlighted in this paper.

\section{Methods}

Materials. The polymers polyvinyl alcohol $\left(\mathrm{C}_{2} \mathrm{H}_{4} \mathrm{O}, \mathrm{Mw}=130,000\right.$ : hydrolysis degree: $\left.99 \%\right)$ and anionic dye, Congo red $\left(\left(\mathrm{C}_{32} \mathrm{H}_{22} \mathrm{~N}_{6} \mathrm{Na}_{2} \mathrm{O}_{6} \mathrm{~S}_{2}\right)\right.$; purity: 99.0\%) was purchased from Ajax Finechem Pvt. Ltd. (Thailand). The crosslinking agent glutaraldehyde $\left(\mathrm{C}_{5} \mathrm{H}_{8} \mathrm{O}_{2}\right)$ were procured from Loba Chemie Products Limited. (Thailand). Sodium alginate $\left(\left(\mathrm{C}_{6} \mathrm{H}_{7} \mathrm{NaO}_{6}\right)_{\mathrm{n}}\right.$, average $\left.\mathrm{Mw}=60,000\right)$ were obtained from Nice chemical Pvt. Ltd. (India). Tetra propyl ammonium hydroxide $\left(\left(\mathrm{CH}_{3} \mathrm{CH}_{2} \mathrm{CH}_{2}\right)_{4} \mathrm{NOH}\right.$, TPAOH), tetraethyl orthosilicate $\left(\mathrm{C}_{8} \mathrm{H}_{20} \mathrm{O}_{4} \mathrm{Si}\right.$, TEOS $)$ and aluminum isopropoxide $\left(\mathrm{C}_{9} \mathrm{H}_{21} \mathrm{AlO}_{3}\right.$, AIP) were procured from Sigma Aldrich Co. Ltd (India). Soluble starch $\left(\mathrm{C}_{6} \mathrm{H}_{10} \mathrm{O}_{5}\right)_{\mathrm{n}}$ which was used as templating agent were of reagent grade and was procured from Merck (India). All the chemicals used in the study were of analytical grade and were used as received without further purification. The polymer solution and dye solution were prepared in distilled water. Figure 1 depicts the chemical structure of the materials used in the study.

Fabrication of hierarchical ZSM-5 zeolite. The procedure for the synthesis of hierarchical ZSM-5 zeolite is briefly described below. To the properly mixed tetra propylammonium hydroxide (TPAOH; $2.11 \mathrm{~g}$ ) and aluminum isopropoxide (AIP; $0.03 \mathrm{~g}$ ) solution, tetraethyl orthosilicate (TEOS; $3.46 \mathrm{~g}$ ) solution was added dropwise with constant stirring for $5 \mathrm{~h}$ at room temperature. This was followed by the addition of meso templating agent, starch $(0.2 \mathrm{~g})$ and the mixture was magnetically stirred for $2 \mathrm{~h}$ to attain homogeneity. The resulting mixture was then concentrated in a rotavapor at $80^{\circ} \mathrm{C}$ for $30 \mathrm{~min}$ until a viscous solution is obtained, which was transferred into a Teflon-lined stainless-steel autoclave, and kept at $80^{\circ} \mathrm{C}$ for $24 \mathrm{~h}$ and crystallized at $175^{\circ} \mathrm{C}$ for $6 \mathrm{~h}$. The solid product was collected, washed with deionized water, dried in air, and calcined at $550^{\circ} \mathrm{C}$ for $5 \mathrm{~h}$ in a muffle furnace to remove the starch and organic structure directing agents ${ }^{55,56}$.

Fabrication of PVA/sodium alginate/ZSM-5 zeolite membrane. PVA/sodium alginate/ZSM-5 zeolite membrane was fabricated by solvent casting method. At first, required amount of polyvinyl alcohol and sodium alginate were dissolved separately in distilled water under constant stirring to obtain 9 and 1.5 wt $\%$ of PVA and SA solution respectively. The resultant solution was then mixed and magnetically stirred for $3 \mathrm{~h}$. Afterwards, hierarchical ZSM-5 zeolite of varying concentration ranging from 0.5 to $2.5 \mathrm{wt} \%$ were added and 
a<smiles>CCC(C)C(C)O</smiles><smiles>[NH2+]OC(=O)C1OC(O)C(O)C(O)C1O</smiles>

b<smiles>CO[Si](O[AlH2])(O[SiH3])O[Si](OC)(O[SiH3])O[SiH3]</smiles>

d

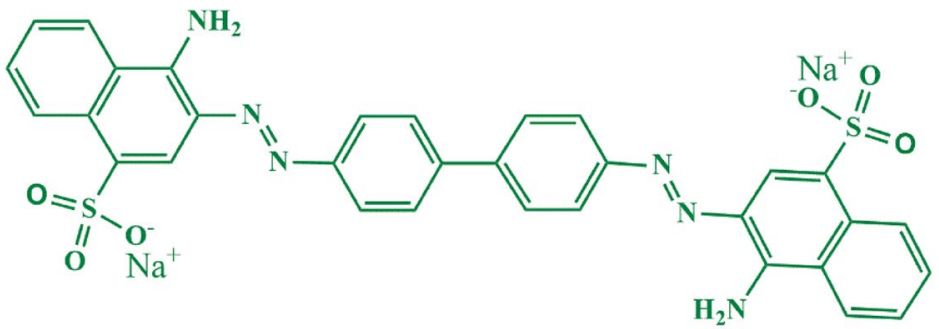

Figure 1. Molecular structures of: (a) PVA, (b) ZSM-5 zeolite, (c), Sodium alginate (d) Congo red dye.

\begin{tabular}{|l|l|l|l|}
\hline Sample code & PVA (wt\%) & SA (wt\%) & ZSM-5 (wt\%) \\
\hline PSZ-0 & 9 & 1.5 & 0 \\
\hline PSZ-1 & 9 & 1.5 & 0.5 \\
\hline PSZ-2 & 9 & 1.5 & 1.5 \\
\hline PSZ-3 & 9 & 1.5 & 2.5 \\
\hline
\end{tabular}

Table 1. The composition of the casting solution.

stirred at room temperature for $2 \mathrm{~h}$ to attain homogeneity. Once the solution was properly homogenized, $0.1 \mathrm{~mL}$ of cross-linker glutaraldehyde $(\mathrm{GA})$ in acidic medium $(\mathrm{HCl})$ were added in dropwise. The blended solution was casted on a petri dish and kept for air drying for a period of 5 days. The membrane was later peeled out from the petri dish and used for adsorption studies. The membranes containing $0,0.5,1.5$ and $2.5 \mathrm{wt} \%$ of ZSM-5 zeolite is designated as PSZ-0, PSZ-1, PSZ-2, and PSZ-3 respectively. Chemical compositions of membranes are displayed in Table 1.

Characterisation. The crystallinity of the PVA/SA/ZSM-5 zeolite membrane was identified by Rigaku miniflex 600 benchtop X-ray diffractometer with $\mathrm{Cu}-\mathrm{Ka}$ radiation as X-ray source. The XRD spectrum was recorded from 5 to $50^{\circ}(2 \theta)$ at a scan rate of $2 \% \mathrm{~min}$. The chemical structure of the membrane was monitored by using Jasco 4,700 FT-IR spectrometer in the range of $450-4,000 \mathrm{~cm}^{-1}$ with $4 \mathrm{~cm}^{-1}$ resolution. A thermogravimetric analyser Mettler Toledo TGA/DSC 3 + HT/1,600 instrument was employed to investigate the thermal stability of membranes. The analysis was carried out in the temperature range of $50-750{ }^{\circ} \mathrm{C}$ at a heating rate of $10^{\circ} \mathrm{C} /$ min in $\mathrm{N}_{2}$ atmosphere. The surface morphology of the membranes was assessed by scanning electron microscope (FEI Quanta 450) and optical microscopy (Olympus BX43 series) instrument. Universal testing machine (QC-506M1-204) was employed to investigate the mechanical properties of the membranes. Static water contact angle of the membranes was probed using Digidrop goniometer. Adsorption experiments were conducted using UV-visible spectrometer Specord (UV-210) at a characteristic wavelength of $492 \mathrm{~nm}$.

Adsorption studies. For adsorption experiments, $0.075 \mathrm{~g}$ of membrane was added to $40 \mathrm{~mL}$ of Congo red solution and stirred at room temperature. After regular time interval the dye solution was withdrawn, filtered and analysed using UV-visible spectrophotometer at a characteristic wavelength of $492 \mathrm{~nm}$. The concentration of Congo red at different time interval was determined from the calibration graph. The percentage dye removal 
efficiency $(R)$ and equilibrium adsorption capacity $\left(\mathrm{q}_{\mathrm{e}}\right)$ of the membrane were calculated using the following equations:

$$
\begin{gathered}
\mathrm{q}_{\mathrm{e}}=\frac{\left(\mathrm{C}_{0}-\mathrm{C}_{\mathrm{e}}\right) \mathrm{V}}{\mathrm{W}} \\
\mathrm{R}=\frac{\mathrm{C}_{0}-\mathrm{C}_{\mathrm{e}}}{\mathrm{C}_{0}} \times 100(\%)
\end{gathered}
$$

Here $\mathrm{C}_{0}$ and $\mathrm{C}_{\mathrm{e}}(\mathrm{mg} / \mathrm{L})$ represent the initial and equilibrium concentrations of Congo red respectively; $\mathrm{V}(\mathrm{L})$ is the volume of Congo red solution and $\mathrm{W}(\mathrm{g})$ is the weight of the dried membrane ${ }^{30}$.

Antibacterial studies. The disk diffusion agar method was employed to assess the antimicrobial property of the PVA/SA/ZSM-5 zeolite membranes. The culture medium was prepared using Muller-Hinton agar seeded with $100 \mu \mathrm{L}$ of bacterial strain (Escherichia coli and Staphylococcus aureus). Membranes were cut in a circular shape with $1 \mathrm{~cm}$ diameter and placed on this agar plates, which was later incubated at $37^{\circ} \mathrm{C}$ for $24 \mathrm{~h}$. The diameter of the inhibition zone formed around the specimens was measured and photographed ${ }^{57,58}$.

Reusability. For recyclability test, $0.075 \mathrm{~g}$ of Congo red loaded membrane is immersed in $0.1 \mathrm{~N} \mathrm{of} \mathrm{HCl}$ under constant stirring for $3 \mathrm{~h}$. The membrane was then separated from acid solution, washed several times with distilled water, dried and reuse for further adsorption process ${ }^{59}$.

\section{Result and discussion}

Polymer with good crystallinity tends to improve the thermal and mechanical stability of the membrane. This prompted us to evaluate the effect of zeolite on the crystalline nature of PVA/SA membrane. The XRD pattern of PVA/SA/ZSM-5 zeolite membrane is shown in Fig. 2a. The crystalline peak centered at $2 \theta=20^{\circ}$, is attributed to the reflection from (100) and (200) plane of PVA and SA ${ }^{60,61}$. Comparison of XRD pattern of pristine PVA/SA membrane with PVA/SA/ZSM-5 zeolite membranes shows that both the membrane possesses similar diffraction pattern. However, with increases in zeolite concentration the intensity of peak at $2 \theta=22-25^{\circ}$ increases; attributed to the characteristic MFI peak of zeolite ${ }^{62}$. The XRD result thus shows that zeolite retains the overall crystallinity of the membrane. FTIR is one of the powerful tools to identify the functional groups and to understand the chemical interaction between molecules. FTIR spectrum of PVA/SA/ZSM-5 zeolite membranes are illustrated in Fig. 2b. The peak observed at $3,233 \mathrm{~cm}^{-1}$ is assigned to the hydroxyl stretching band of PVA, sodium alginate and zeolite ${ }^{63}$. The alkyl stretching present in PVA, sodium alginate and zeolite can be seen at $2,915 \mathrm{~cm}^{-1}$ and the sharp peak centered at $1,630 \mathrm{~cm}^{-1}$ is assigned to the characteristic $\mathrm{C}=\mathrm{O}$ stretching of carboxyl group of sodium alginate ${ }^{64}$. A prominent band at $1,075 \mathrm{~cm}^{-1}$ can be seen in the FTIR spectra and is attributed to the acetal bridge (C-O-C) present in the crosslinked structure of PVA and GA. In the case of zeolite loaded membrane, we can observe a new peak at $550 \mathrm{~cm}^{-1}$, assigned as the characteristic structure of zeolite ${ }^{30}$. The intensity of this characteristics peak is found to increase with zeolite content, thus confirming successful incorporation of zeolite in PVA/ SA membrane. A prominent blue shift observed in the characteristic peak of zeolite indicates the formation of hydrogen bond between PVA and zeolite (Fig (S1)). Contact angle measurement is an important analysis which is used to elucidate the hydrophilicity or wettability of the membrane. Perhaps, contact angle and hydrophilicity is inversely related to each other. Membrane with low contact angle is said to possess high hydrophilic character. On the other hand, a high value of contact angle implies greater hydrophobicity. The contact angle measurement of PVA/SA/ZSM-5 zeolite membrane is presented in Fig. 2c. It can be seen from Fig. 2c that the PVA/ SA membrane possess low contact angle $\left(23.5^{\circ}\right)$. This could be due to the presence of hydrophilic functional groups such as $-\mathrm{OH}$ and $-\mathrm{COOH}$. However, the contact angle of PVA/SA/ZSM-5 zeolite membrane is relatively higher than pristine membrane and its value is found to escalates from $23.5^{\circ}$ to $81.93^{\circ}$ with zeolite loading. This implies that PVA/SA/ZSM-5 zeolite membrane is less hydrophilic than pristine membrane. Therefore, the water drop placed on the surface of zeolite loaded membrane becomes more spherical (Fig. 2c) with increasing zeolite content. This is agreement with the previous report ${ }^{65,66}$. The thermal behavior of the membrane was examined using TGA analysis and the result is presented in Fig. $2 \mathrm{~d}$. It can be noticed that the membranes exhibit weight loss in three stages. The initial weight loss occurred in the temperature range $50-150{ }^{\circ} \mathrm{C}$ corresponds to the removal of loosely bound moisture in the membrane. The second stage of degradation around 170 to $310^{\circ} \mathrm{C}$ is due to decomposition of PVA and sodium alginate. Final stage observed around $330-520^{\circ} \mathrm{C}$ corresponds to degradation of zeolite crystals ${ }^{2,67}$. Wang et al. ${ }^{68}$ noted a similar degradation temperature $\left(100,200\right.$ and $\left.>350{ }^{\circ} \mathrm{C}\right)$ for PVA/SA/ZSM-5 zeolite membrane and is ascribed to the removal of water, PVA, SA and zeolite from the membrane framework. It is evident from Fig. $2 \mathrm{~d}$ that weight loss and the slope of degradation gets gradually reduced from membrane PSZ-0 to PSZ-3 (84.82\% to 58.37\%). This is expected owing to the high zeolite content which increases the thermal stability of the membrane. Mechanical strength and mechanical stability are important factor for membrane studies. Earlier report shows that addition of nanoparticles such as zeolites, clay, laponite will improve the polymer stability ${ }^{69,70}$. The mechanical properties of different membrane were shown in Fig. 2e. An improvement in the tensile strength of the membrane with zeolite percentage was noted. This is attributed to the enhancement of chemical interaction between the zeolite and polymer matrix. However, the elongation at break decrease with zeolite content. Prasad et al. also observed a similar type of behavior for PVA/ SA/ZSM-5 zeolite system ${ }^{71}$.

The effect of zeolite on the surface morphology of the pristine PVA/SA membrane was evaluated using SEM and optical microscopic technique. The surface morphology of pristine PVA/SA and PVA/SA membrane loaded 

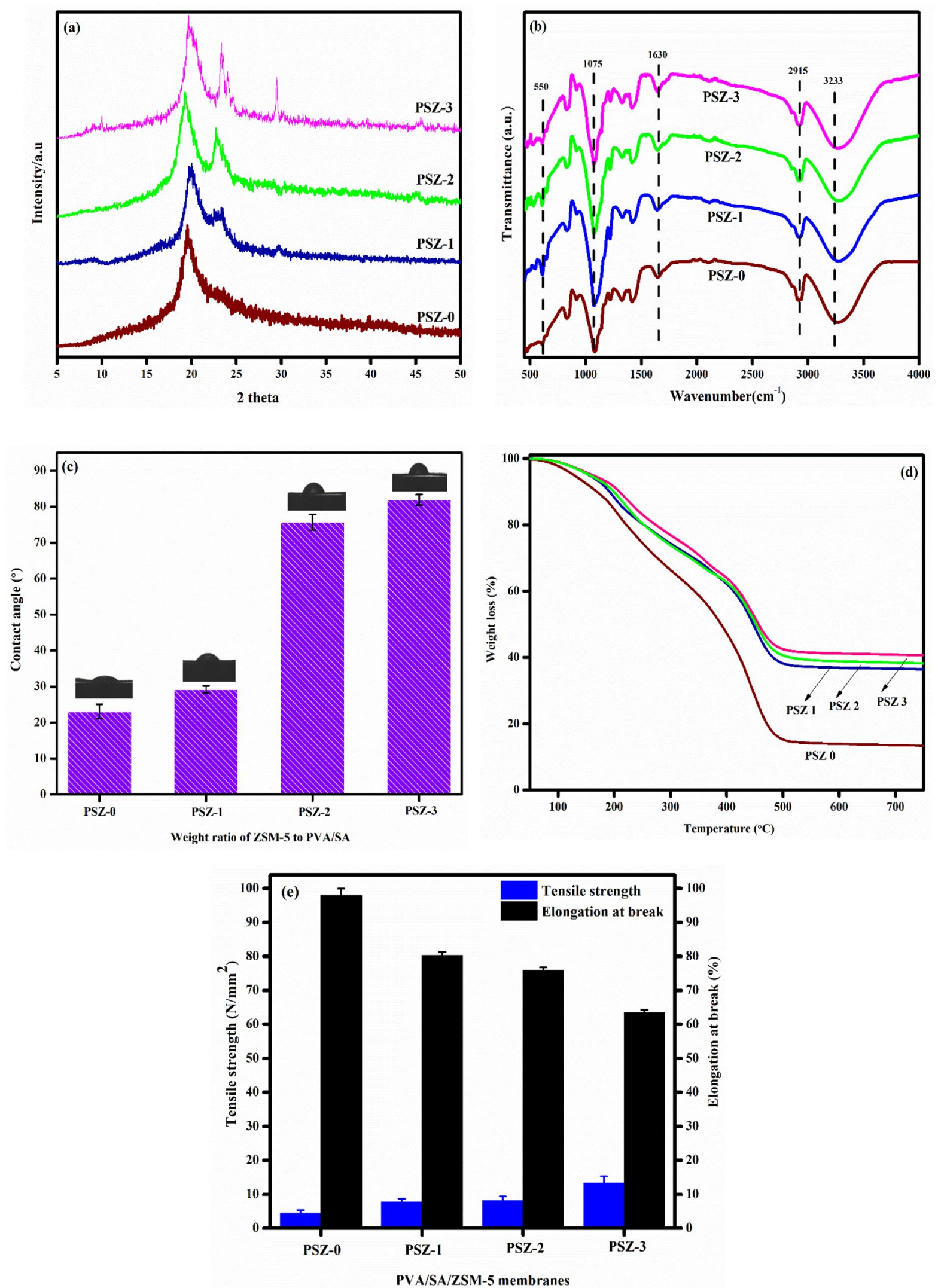

Figure 2. (a) XRD, (b) FTIR (c) contact angle (d) TGA and (e) mechanical properties of PVA/SA/ZSM-5 zeolite membranes. 
(I)
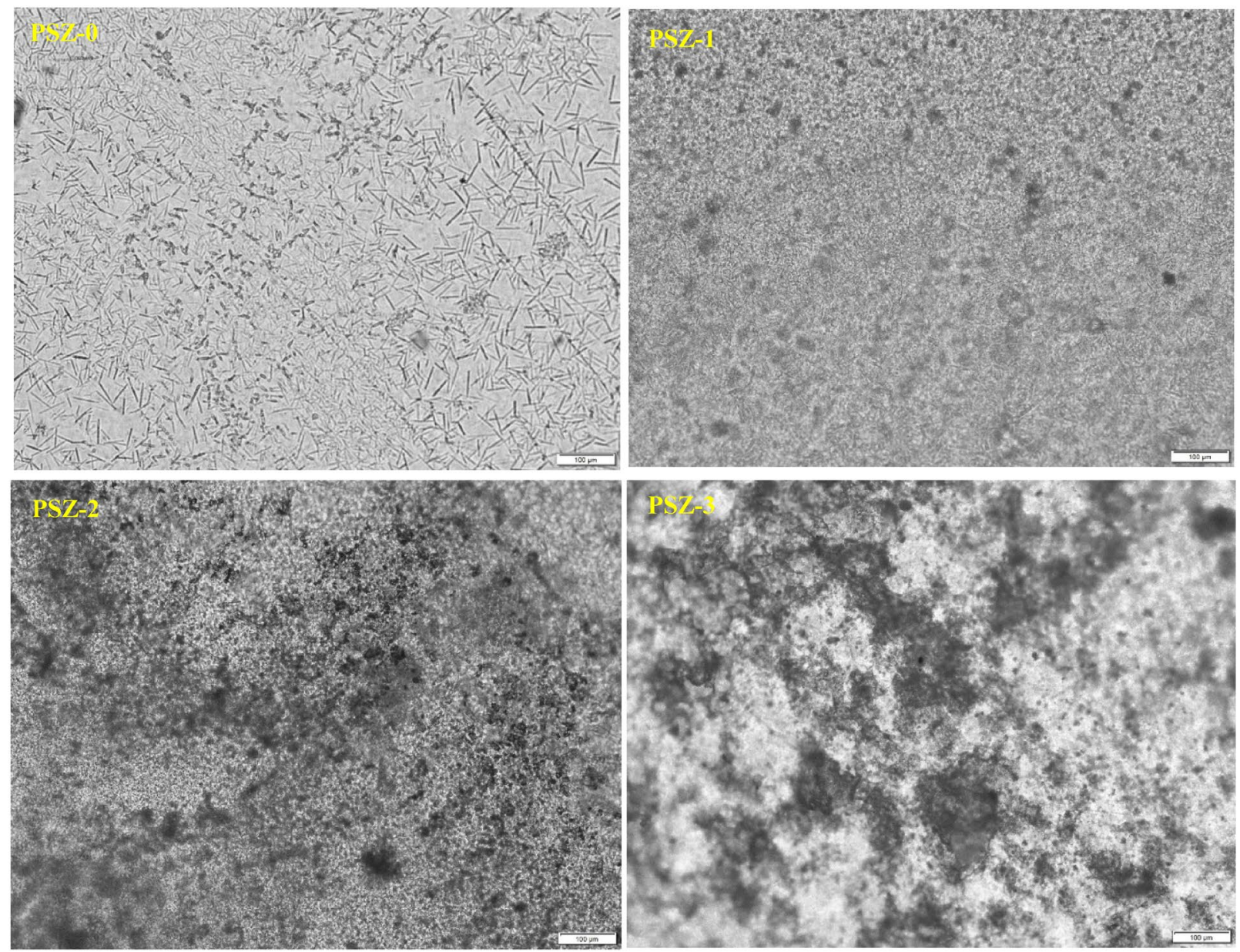

Figure 3. (I) Optical microscopic and (II) SEM image of PVA/SA/ZSM-5 zeolite membranes with low and high magnifications.

with different percentage of zeolite (PSZ-1 to PSZ-3) is presented in Fig. 3(I,II). It can be seen from Fig. 3 that PVA/SA possesses a rod like morphology. On the other hand, PVA/SA/ZSM-5 zeolite membranes displayed a large number of cubic particles on the surface of polymer matrix; attributed to the presence of zeolite. With increase in zeolite percentage, the distribution of these particles is found to increase and at high concentration, a slight agglomeration can be noted. The SEM analysis thus proved that zeolite particle is successfully incorporated in PVA/SA membrane. Optical microscopic images were in complimentary to SEM analysis and supports the distribution of zeolite in the polymer matrix (Fig. 3(II)).

Adsorption studies. The adsorption ability of the prepared membranes was tested using a model anion dye, Congo red. The effect of operation parameters such as zeolite loading, initial dye concentration, contact time, $\mathrm{pH}$ and temperature on the adsorption behavior of the membranes was investigated in detail. Zeolite is one of the versatile materials with high surface area and has been widely used for the adsorption of dyes, toxic metal and gases ${ }^{43}$. Our previous reports show that it is an excellent adsorbent for the removal of methylene blue (MB) and methyl orange $(\mathrm{MO})$ from aqueous solution ${ }^{54,72}$. In order to optimize the adsorbent dosage, we have varied the zeolite dosage from 0.5 to $2.5 \mathrm{wt} \%$ and investigated its effect on the adsorption capacity of the membrane. It can be deduced from Fig. 4a that with increase in zeolite dosage, the adsorption capacity increases and the membrane loaded with $2.5 \mathrm{wt} \%$ of zeolite exhibits maximum adsorption capacity ( $5.33 \mathrm{mg} / \mathrm{g})$. The linear increase in the adsorption capacity with adsorbent dosage is in agreement with the previous reported work and could be explained on the basis of availability of vacant active site on the membrane $\mathrm{e}^{73}$. With increase in zeolite content, the number of active site and surface area of the membrane increases. Thus, zeolite provides a favorable environment for the adsorption of Congo red onto the membrane. Our observation agrees well with the work of Briao et al. ${ }^{74}$ The authors noticed a significant enhancement in the adsorption capacity of chitin/zeolite membrane for crystal violet with zeolite dosage. Initial dye concentration plays a significant role in dye adsorption process. The effect of initial dye concentration on the adsorption capacity and percentage dye removal was investigated by varying initial dye concentration from 10 to $50 \mathrm{ppm}$ and the results are presented in Fig. 4b. It is evident from Fig. $4 \mathrm{~b}$ that with increase in $\mathrm{C}_{\mathrm{o}}$, the $\mathrm{q}_{\mathrm{e}}$ increases from 5.33 to $24.45 \mathrm{mg} / \mathrm{g}$, while the removal efficiency decreases from 99.9 to $90 \%$. Our result is in consistent with the previous reports which stated that initial dye concentration renders necessary driving force to reduce the resistance of mass transfer from liquid to solid phase ${ }^{75}$. Consequently, the 
(II)
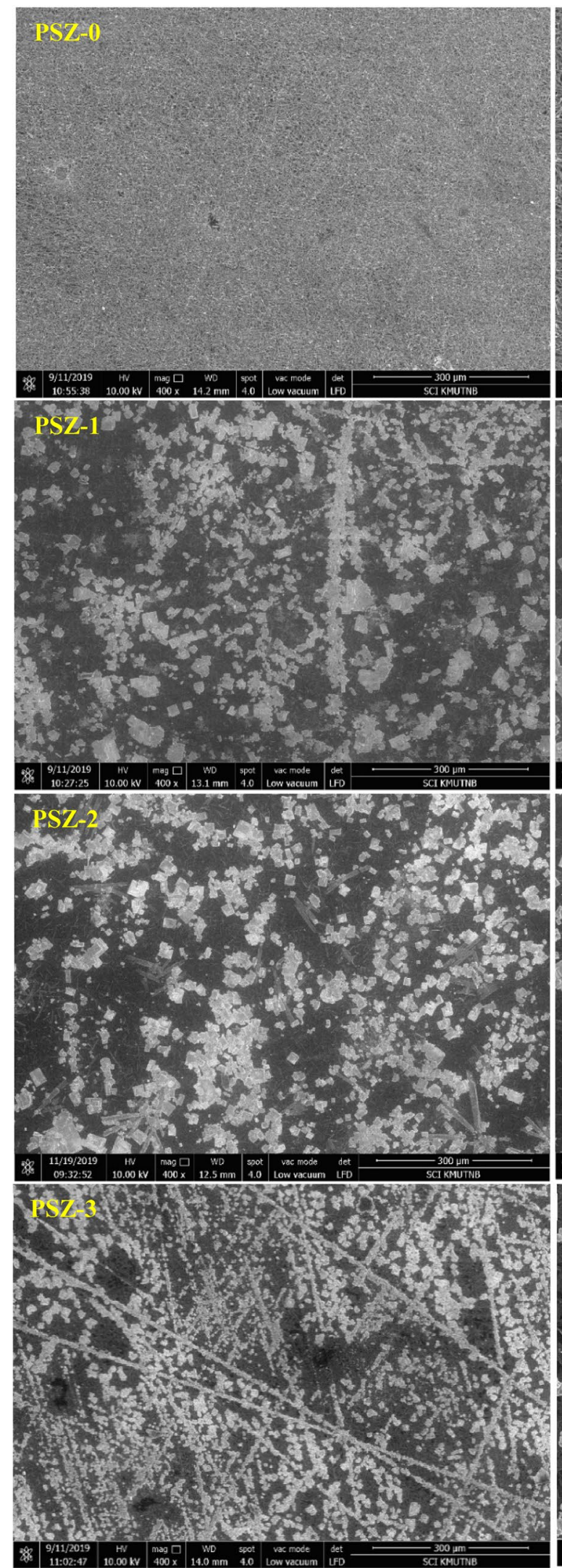

Figure 3. (continued)
PST $=0$
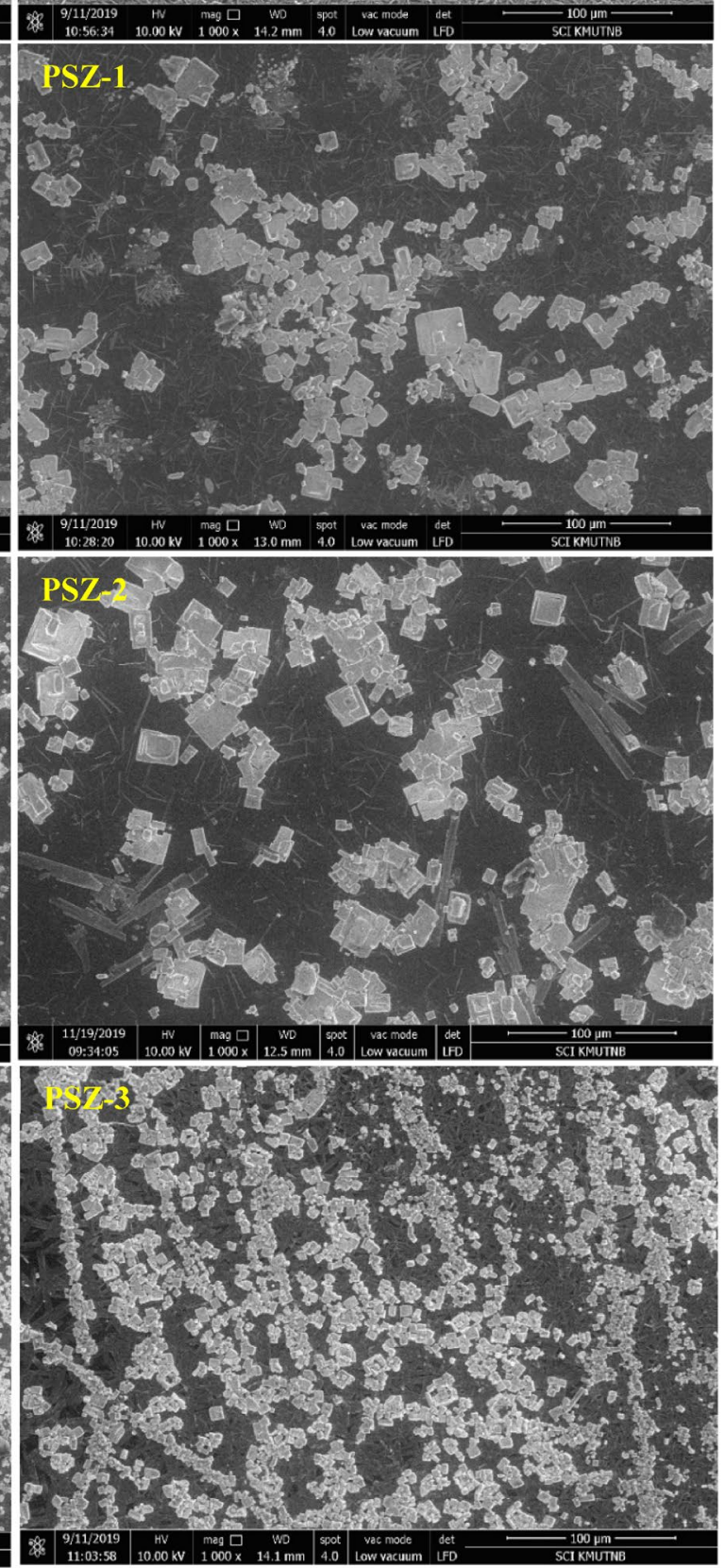
collision between dye and the adsorbent increases and the adsorption process become more favorable. Baheri et al. ${ }^{76}$ reported that that adsorption capacity of PVA/4A zeolite membrane for methylene blue (MB) dye rises from 4.90 to $41.08 \mathrm{mg} / \mathrm{g}$ on increasing the initial dye concentration from 5 to $100 \mathrm{mg} / \mathrm{g}$. The decreases in dye removal percentage with initial concentration of Congo red dye is attributed to the saturation of active site under high concentration condition of Congo red $^{77}$. Contact time is an important parameter in dye adsorption studies. The effect of contact time on the Congo red removal is depicted in Fig. 4c. It can be noted that during the initial period the adsorption capacity shoots up sharply and after $2.5 \mathrm{~h}$ it almost attain equilibrium. This is probably due to the availability of large number of active sites in the initial phase of the adsorption process which facilitates the binding of Congo red onto the membrane. However, with passage of time as more and more dye molecules get adsorbed on the surface of the membrane the adsorption process become less favoured. Eventually, all active sites get occupied by dye molecules and the adsorption capacity remains almost constant ${ }^{78}$. Chen et al. ${ }^{79}$ reported that on increasing the contact time from 20 to $180 \mathrm{~min}$, Congo red adsorption capacity of PDA@ DCA-COOH membrane enhances from $30 \mathrm{mg} / \mathrm{g}$ to $79.33 \mathrm{mg} / \mathrm{g}$. After $180 \mathrm{~min}$, no further improvement in the adsorption capacity was noted and thus the authors selected $180 \mathrm{~min}$ for performing the adsorption studies. Solution temperature is reported to influence the adsorption behavior of the membrane. The variation of temperature on the dye uptake ability of PVA/SA/ZSM-5 zeolite membrane is shown in Fig. 4d. It can be noted that the adsorption capacity drops from 5.33 to $4.62 \mathrm{mg} / \mathrm{g}$ on increasing the solution temperature from 30 to $60{ }^{\circ} \mathrm{C}$. The negative effect of temperature on the adsorption capacity could be correlated with previous reported work and implies that Congo red adsorption onto the membrane is exothermic in nature ${ }^{80}$. Another plausible reason could be the weakening of electrostatic interaction between dye and the membrane with temperature. Thus, we can conclude that high temperature is unfavorable for the adsorption of Congo red by PVA/SA/ZSM- 5 zeolite membrane. Solution $\mathrm{pH}$ play a crucial role in dye adsorption studies, especially if the mechanism of adsorption is electrostatic in nature. A change in solution $\mathrm{pH}$ will alter the properties of both dye as well as the adsorbent. Therefore, optimizing solution $\mathrm{pH}$ is a necessary requirement for adsorption process. The role of $\mathrm{pH}$ on the Congo red adsorption by PVA/SA/ZSM- 5 zeolite membrane was studied by varying the $\mathrm{pH}$ from 3 to 11 . It can be seen from Fig. $4 \mathrm{e}$ that with increase in $\mathrm{pH}$, the adsorption capacity of the membrane decreases from 5.33 to $2.92 \mathrm{mg} / \mathrm{g}$. This could be due to difference in the surface charge of the membrane with $\mathrm{pH}$. At low $\mathrm{pH}$, the surface of membrane gets protonated and thus attracts anionic Congo red ${ }^{81}$. However, in basic $\mathrm{pH}$ the membrane surface tends to become negative and repel the anionic Congo red. In addition to this, high pH increases the competition between Congo red dye and hydroxide $\left(\mathrm{OH}^{-}\right)$for the same adsorption site.

Adsorption isotherm. Knowledge of adsorption isotherm is essential to design the adsorption system, as it shed light on adsorbate-adsorbent interaction and adsorption capacity of the adsorbent. Freundlich, Langmuir, Temkin and Dubinin-Radushkevich isotherm models are commonly used to understand the adsorption process $^{79,81}$. In the present work, the adsorption behavior of the prepared membrane was evaluated using Freundlich and Langmuir isotherm models.

Langmuir model. According to Langmuir model, the surface of adsorbent is homogenous and possesses finite number of energetically equivalent adsorption sites. This model thus suggests a uniform adsorption of adsorbate on the surface of adsorbent and neglects any interaction between the adsorbed molecules ${ }^{78}$. Langmuir model is given by the following expression.

$$
\mathrm{q}_{\mathrm{e}}=\frac{\mathrm{q}_{\mathrm{m}} \mathrm{K}_{\mathrm{L}} \mathrm{C}_{\mathrm{e}}}{1+\mathrm{K}_{\mathrm{L}} \mathrm{C}_{\mathrm{e}}}
$$

Here, $\mathrm{q}_{\mathrm{e}}$ corresponds to the equilibrium amount of adsorbate or adsorption capacity $(\mathrm{mg} / \mathrm{g})$, while $\mathrm{C}_{\mathrm{e}}$ represents equilibrium concentration of adsorbate $(\mathrm{mg} / \mathrm{L})$. $\mathrm{K}_{\mathrm{L}}$ and $\mathrm{q}_{\mathrm{m}}$ represent Langmuir constant and is related to adsorption energy and adsorption capacity respectively. The linear form of Langmuir isotherm model is expressed as follows

$$
\frac{\mathrm{C}_{\mathrm{e}}}{\mathrm{q}_{\mathrm{e}}}=\left(\frac{\mathrm{C}_{\mathrm{e}}}{\mathrm{q}_{\mathrm{m}}}\right)+\left(\frac{1}{\mathrm{~K}_{\mathrm{L}} * \mathrm{q}_{\mathrm{m}}}\right)
$$

The plot of $\mathrm{C}_{\mathrm{e}} / \mathrm{q}_{\mathrm{e}}$ vs $\mathrm{C}_{\mathrm{e}}$ results in a straight line with $\mathrm{q}_{\mathrm{m}}$ as slope and $\mathrm{K}_{\mathrm{L}}$ as intercept. Another important parameter obtained from Langmuir model is Langmuir separation factor, $\mathrm{R}_{\mathrm{L}}$. This dimensionless constant can be used to predict the feasibility and favorability of the adsorption process. The adsorption is said to be favorable if $R_{L}$ is between 0 and 1 , irreversible if $R_{L}=0$, linear if $R_{L}=1$ and unfavorable if $R_{L}>1$. $R_{L}$ is related to $K_{L}$ and $C_{o}$ by the following expression.

$$
\mathrm{R}_{\mathrm{L}}=\frac{1}{1+\mathrm{K}_{\mathrm{L}} \mathrm{C}_{0}}
$$

Freundlich model. This model assumes non-uniform distribution of adsorbate on the surface of adsorbent and describes a multilayer adsorption. The non-linear form of Freundlich isotherm is given below;

$$
\mathrm{q}_{\mathrm{e}}=\mathrm{K}_{\mathrm{F}} \mathrm{C}_{\mathrm{eq}}^{1 / \mathrm{n}}
$$



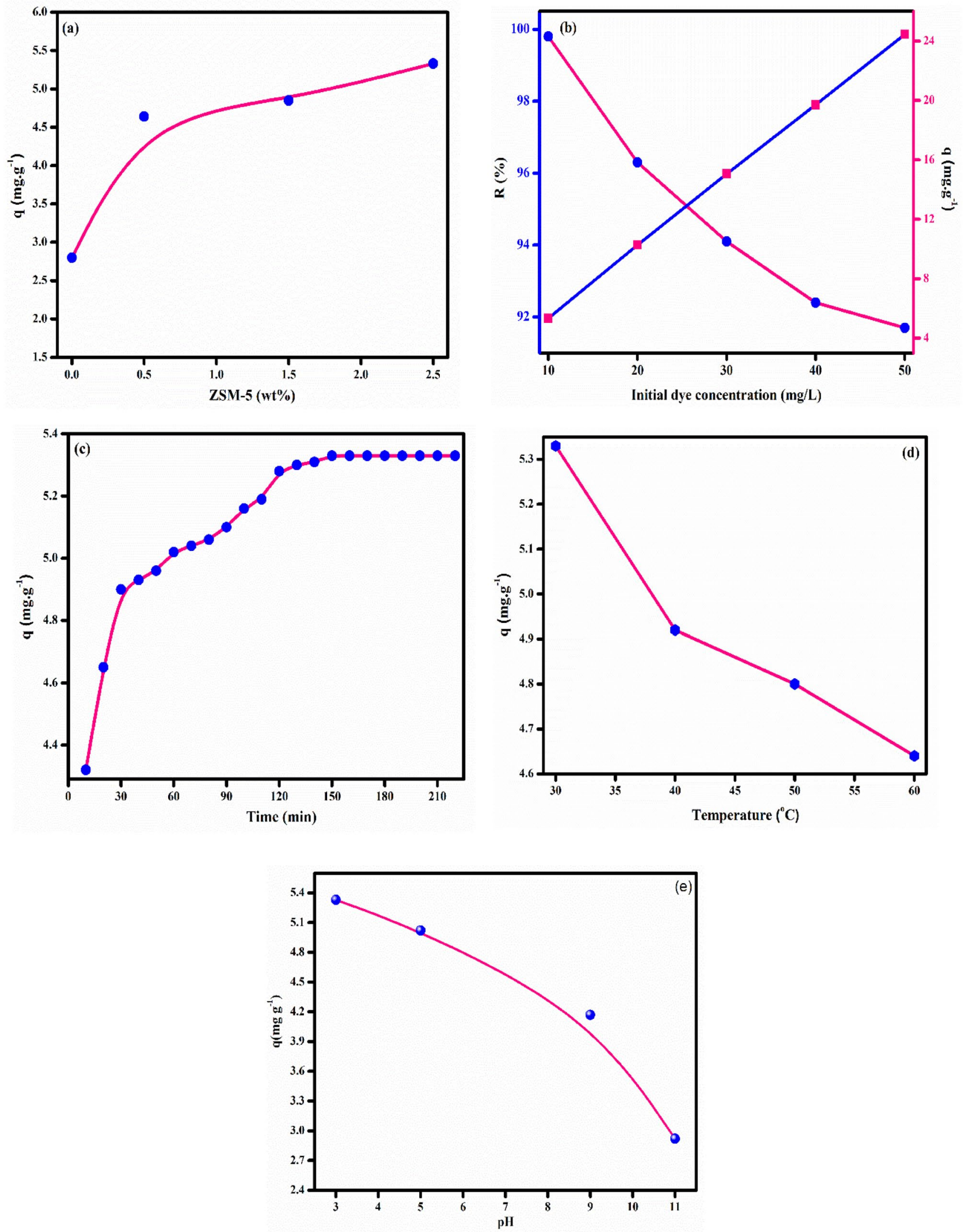

Figure 4. Effect of different parameters (a) zeolite dosage, (b) initial dye concentration, (c) contact time, (d) temperature, (e) $\mathrm{pH}$ on adsorption of Congo red onto PVA/SA/ZSM-5 zeolite membrane (adsorbent dosage $=2.5 \mathrm{wt} \%$, initial $\mathrm{CR}$ concentration $=10 \mathrm{ppm}$, contact time $=130 \mathrm{~min}, \mathrm{pH}=3$ and temperature $=30^{\circ} \mathrm{C}$ ). 

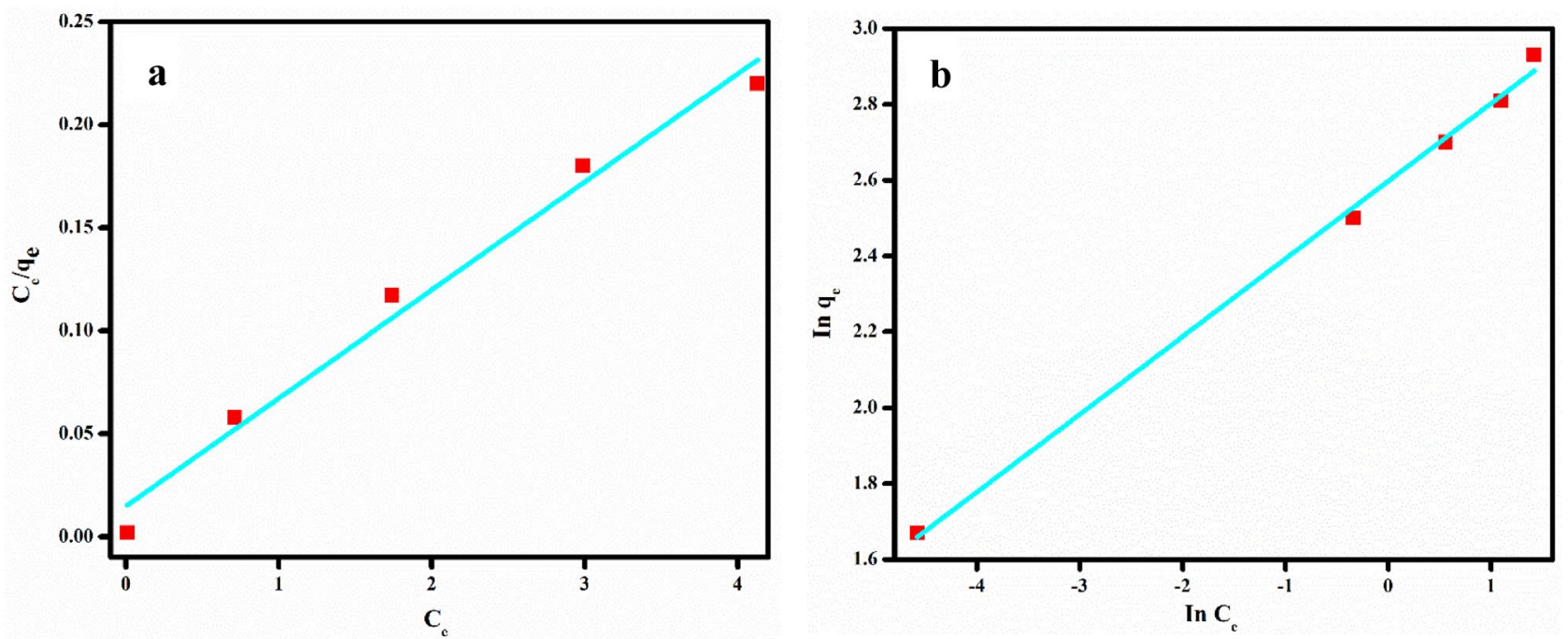

Figure 5. (a) Langmuir and (b) Freundlich isotherm plot for the adsorption of Congo red onto PVA/SA/ZSM-5 zeolite membrane (adsorbent dosage $=2.5 \mathrm{wt} \%$, initial CR concentration $=10 \mathrm{ppm}$, contact time $=130 \mathrm{~min}$, $\mathrm{pH}=3$ and temperature $=30^{\circ} \mathrm{C}$ ).

\begin{tabular}{|l|l|l|l|l|l|l|}
\hline Exp & Langmuir & Freundlich & \\
\hline $\mathbf{q}_{\mathbf{e}}, \exp (\mathbf{m g} / \mathbf{g})$ & $\mathbf{q}_{\mathbf{m}}(\mathbf{m g} / \mathbf{g})$ & $\mathbf{K}_{\mathbf{L}}$ & $\mathbf{R}^{\mathbf{2}}$ & $\mathbf{K}_{\mathbf{F}}(\mathbf{m g} / \mathbf{g})$ & $\mathbf{n}$ & $\mathbf{R}^{\mathbf{2}}$ \\
\hline 5.33 & 19 & 3.54 & 0.99 & 4.8 & 4.4 & 0.998 \\
\hline
\end{tabular}

Table 2. Adsorption isotherm parameters of Congo red onto PVA/SA/ZSM-5 zeolite membrane.

Pseudo-first order

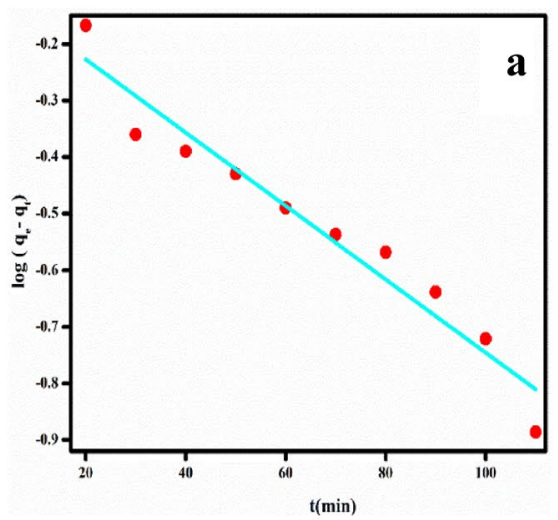

Pseudo-second order

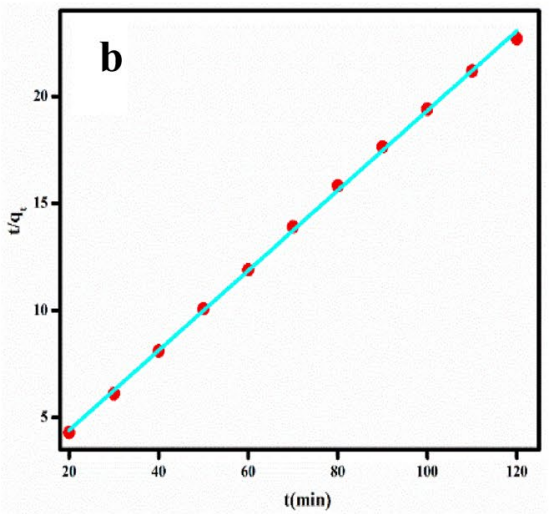

Intra-particle diffusion

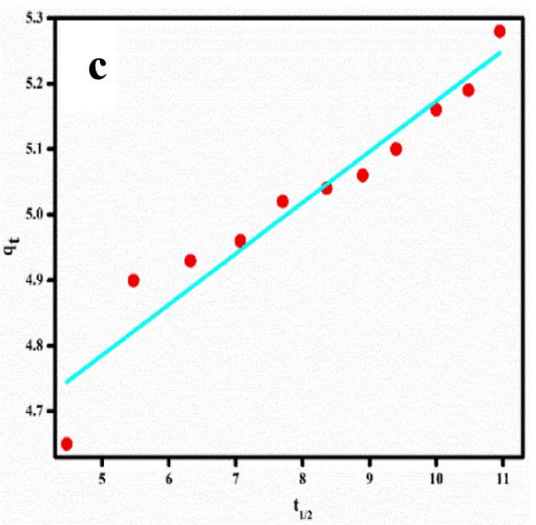

Figure 6. Plots of the pseudo-first, pseudo-second and intra-particle diffusion model for Congo red adsorption onto PVA/SA/ZSM-5 zeolite membrane (adsorbent dosage $=2.5 \mathrm{wt} \%$, initial CR concentration $=10 \mathrm{ppm}$, contact time $=130 \mathrm{~min}, \mathrm{pH}=3$ and temperature $\left.=30^{\circ} \mathrm{C}\right)$.

\begin{tabular}{|c|c|c|c|c|c|c|c|c|c|}
\hline Exp & Pseudo-first & order & & Pseudo-second-orc & & & Intra-parti & usion & \\
\hline $\mathbf{q}_{\mathrm{e}}, \exp \left(\mathrm{mg} \mathrm{g}^{-1}\right)$ & $K_{1}\left(\min ^{-1}\right)$ & $\mathbf{q}_{\mathrm{e}}\left(\mathrm{mg} \mathrm{g}^{-1}\right)$ & $\mathbf{R}^{2}$ & $\mathrm{~K}_{2}\left(\mathrm{~g} \mathrm{mg}^{-1} \min ^{-1}\right)$ & $q_{e}\left(\mathrm{mg} \mathrm{g}^{-1}\right)$ & $\mathbf{R}^{2}$ & $\begin{array}{l}\mathrm{K}_{\mathrm{id}}(\mathrm{g} \mathrm{mg} \\
\left.{ }_{1} \mathbf{m i n}^{-1 / 2}\right)\end{array}$ & $\mathrm{C}\left(\mathrm{mg} \mathrm{g}^{-1}\right)$ & $\mathbf{R}^{2}$ \\
\hline 5.33 & 0.0147 & 1.1 & 0.972 & 0.0508 & 5.36 & 0.999 & 0.077 & 4.39 & 0.91 \\
\hline
\end{tabular}

Table 3. Kinetic parameter values for the Congo red adsorption on zeolite loaded PVA/SA membrane. 

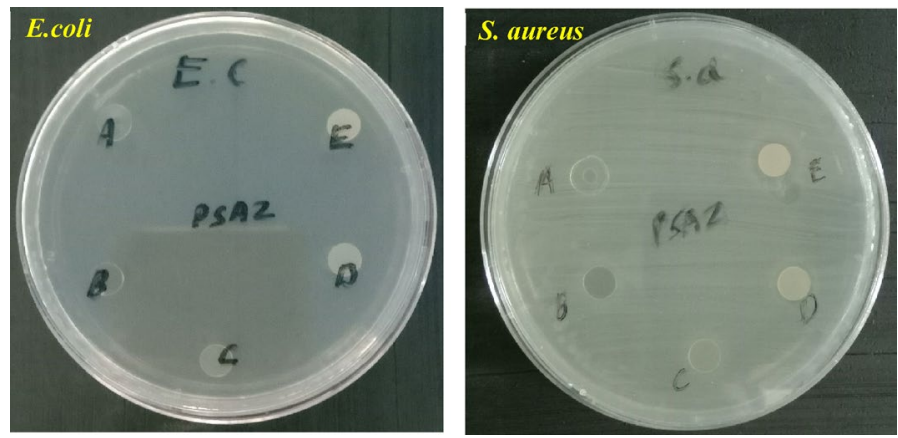

Figure 7. Photograph of antimicrobial test of different percentage of zeolite loaded on PVA/SA membrane against gram-negative and gram-positive: (A) PVA, (B) PSZ-0, (C) PSZ-1, (D) PSZ-2, (E) PSZ-3.

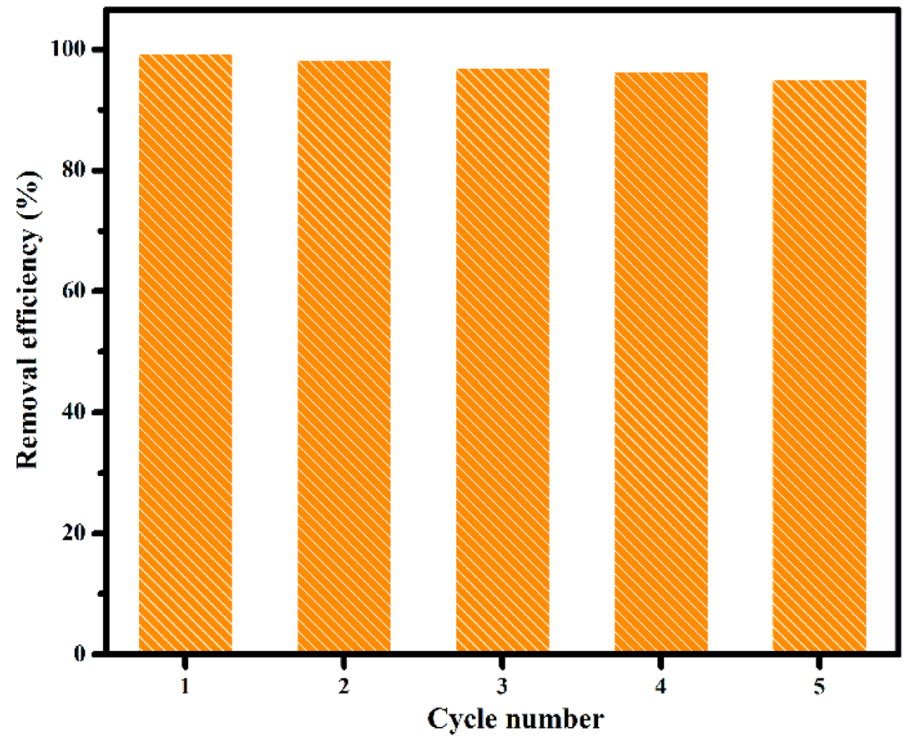

Figure 8. Recyclability test of Congo red adsorption on PVA/SA/ZSM-5 zeolite membrane.

where $q_{e}$ is the amount of Congo red adsorbed onto the membrane at equilibrium $(\mathrm{mg} / \mathrm{g})$ and $\mathrm{C}_{\mathrm{e}}$ is the equilibrium concentration of Congo red in solution $(\mathrm{mg} / \mathrm{L}) . \mathrm{K}_{\mathrm{F}}$ and $1 / n$ are adsorption capacity and adsorption intensity (surface homogeneity) which is obtained from the slope and intercept of the plot between $\ln \mathrm{q}_{\mathrm{e}}$ and $\ln$ $\mathrm{C}_{\mathrm{e}}$ respectively. The value of $1 / n$ is indicative of favorability of the adsorption. For instance, $1 / n$ value between 0 and 1 implies favorable adsorption while $1 / n>0$ and equal to zero is considered as irreversible and unfavorable adsorption respectively ${ }^{82}$.

The linear form of Freundlich isotherm is represented as follows;

$$
\ln \left(\mathrm{q}_{\mathrm{e}}\right)=\operatorname{In} \mathrm{K}_{\mathrm{F}}+\frac{1}{\mathrm{n}} * \operatorname{In}\left(\mathrm{C}_{\mathrm{e}}\right)
$$

The applicability of these two models to explain the Congo red adsorption onto PVA/SA/ZSM-5 zeolite membrane was verified by fitting the experimental adsorption data into the models (Fig. 5a,b) and the characteristic isotherm parameters derived from the isotherm models are presented in Table 2. It is evident from Fig. 5 that the experimental adsorption data fitted well with Freundlich model with high correlation ratio, $\left(\mathrm{R}^{2}: 0.9985\right)$. Also, there is good agreement between calculated $(4.8 \mathrm{mg} / \mathrm{g})$ and experimental $\mathrm{q}_{\mathrm{e}}$ value $(5.33 \mathrm{mg} / \mathrm{g})$ thus suggesting that the Freundlich isotherm model is more suitable to describe the adsorption of Congo red onto PVA/SA/ ZSM-5 zeolite membrane and involves a multilayer adsorption process. The value of Freundlich constant, $n$ was found to be 4.4 (Table 2), implying the favourable nature of adsorption process ${ }^{83}$.

Adsorption kinetics. Adsorption kinetics gives an idea about the controlling mechanism of adsorption process (chemical reaction, diffusion and mass transfer process) and provides information regarding adsorption rate and adsorbate residue time. To investigate the kinetics of Congo red adsorption on the PVA/SA/ZSM-5 zeo- 
lite membrane pseudo-first-order (PFO), pseudo-second-order (PSO) and intra-particle diffusion model were employed. The linear form of PFO and PSO is given below.

PFO model

$$
\log \left(\mathrm{q}_{\mathrm{e}}-\mathrm{q}_{\mathrm{t}}\right)=\log \mathrm{q}_{\mathrm{e}}-\frac{\mathrm{K}_{1} \mathrm{t}}{2.303}
$$

PSO model

$$
\frac{\mathrm{t}}{\mathrm{q}_{\mathrm{e}}}=\frac{1}{\mathrm{~K}_{2} \mathrm{q}_{\mathrm{e}}^{2}}+\frac{\mathrm{t}}{\mathrm{q}_{\mathrm{e}}}
$$

where $\mathrm{K}_{1}\left(\mathrm{~min}^{-1}\right)$ is the pseudo-first-order rate constant, $\mathrm{K}_{2}\left(\mathrm{~g} / \mathrm{mg} \mathrm{min}^{-1}\right)$ is the pseudo-second-order rate constant, $\mathrm{q}_{\mathrm{t}}(\mathrm{mg} / \mathrm{g})$ is the adsorption capacity at time $\mathrm{t}(\mathrm{min})$ and $\mathrm{q}_{\mathrm{e}}(\mathrm{mg} / \mathrm{g})$ is the adsorption capacity at equilibrium respectively, which is determined from the slope of $\log \left(\mathrm{q}_{\mathrm{e}}-\mathrm{q}_{\mathrm{t}}\right)$ versus time and $\mathrm{t} / \mathrm{qt}$ versus time of linear plot.

According to intra-particle diffusion model, the kinetics of adsorption involves diffusion of adsorbent into the pores of adsorbent and is represented as

$$
\mathrm{q}_{\mathrm{t}}=\mathrm{K}_{\mathrm{id}} \mathrm{t}^{1 / 2}
$$

where $\mathrm{K}_{\mathrm{id}}$ and $\mathrm{C}$ are intraparticle constants and is estimated from the slope and intercept of the plot between $\mathrm{q}_{\mathrm{t}} \mathrm{vs} \mathrm{t}^{1 / 2}$.

The kinetics of Congo red adsorption onto PVA/SA/ZSM-5 zeolite membrane was assessed by fitting the experimental kinetic data into the linearized form of PFO, PSO and intraparticle diffusion models (Fig. 6). The kinetic parameters obtained from the result are displayed in Table 3. It is evident from figure that our data fitted well in PSO model $\left(\mathrm{R}^{2}-0.999\right)$ and the experimental value was very much close to the $\mathrm{q}_{\mathrm{e}}$ value predicted using PSO model. This implies the suitability of the PSO model for describing the kinetic mechanism of Congo red adsorption on PVA/SA/ZSM-5 zeolite membrane.

An adsorbent with good antibacterial property is beneficial for water treatment application. This prompted us to investigate the antibacterial property of the prepared membrane. The antimicrobial activity of pure PVA, PVA/SA and zeolite loaded PVA/SA was tested against gram-negative (E. coli) and gram-positive (S. aureus) by inhibition zone method (Fig. 7). Absence of inhibition zones surrounding the PVA/SA membrane, suggest that pristine PVA/SA membrane have no antibacterial property. One can observe that zeolite loaded membrane displayed significant inhibition action against gram-positive (S. aureus) and gram negative bacteria (E. coli). The diameter of inhibition zone is found to increase with zeolite content thus indicating that the antibacterial property of the PVA/SA membrane could be improved by incorporating ZSM-5 zeolite. The mechanism of action of zeolite on gram-positive bacteria remains uncertain. But, we presume that negatively charged zeolite could easily bind with the surface of gram-positive bacteria and causes the disruption of cell wall. This perhaps leads to the leakage of cellular material and leads to bacterial death. The weak inhibition action of zeolite against gram-negative bacteria could be due to the repulsion between zeolite and negatively charged surface of gram-negative bacteria.

Reusability test is generally employed to access the practicability of the membrane. So, in the present study we subjected the membrane to five desorption-adsorption cycle and the results is presented in Fig. 8. It is evident from the Fig. 8 that the membrane possesses good regeneration capacity even after 5 cycle. The small decrease in the removal efficiency while going from first (99.3\%) to firth cycle (95.1\%) could be due to the incomplete desorption of Congo red from the membrane ${ }^{84}$.

\section{Conclusion}

In this work, we have successfully developed an ecofriendly adsorbent for the removal of toxic anionic dye, Congo red from aqueous medium. Based on different characterization technique's such as XRD, FTIR, TGA and contact angle we found that the membrane is stable and the properties of the membrane such as crystallinity, thermal stability and hydrophilicity could be tuned by varying zeolite content. SEM and optical analysis revealed that the zeolite particle is successfully incorporated in the polymer matrix. The membrane was tested for Congo red removal from water. The optimized condition for the removal of Congo red from membrane is found to be as follows: zeolite content $=2.5 \mathrm{wt} \%$; initial CR concentration $=10 \mathrm{ppm}$, contact time $=130 \mathrm{~min}$, temperature $=30^{\circ} \mathrm{C}$ and $\mathrm{pH}=3$. The adsorption isotherm and kinetics analysis revealed that the adsorption can be best described by Freundlich and PSO model respectively. The prepared membrane also possesses prominent antibacterial property and recyclability. Thus, from the current work, we can conclude that PVA/SA/ZSM-5 zeolite membrane could be a promising candidate for the removal of Congo red from polluted water.

Received: 14 May 2020; Accepted: 27 July 2020

Published online: 22 September 2020

\section{References}

1. Tchounwou, P. B., Yedjou, C. G., Patlolla, A. K. \& Sutton, D. J. In Molecular, Clinical and Environmental Toxicology Experientia Supplementum Ch. Chapter 6, 133-164 (2012).

2. Amirilargani, M. \& Sadatnia, B. Poly(vinyl alcohol)/zeolitic imidazolate frameworks (ZIF-8) mixed matrix membranes for pervaporation dehydration of isopropanol. J. Membr. Sci. 469, 1-10. https://doi.org/10.1016/j.memsci.2014.06.034 (2014).

3. Agrawal, A., Pandey, R. S. \& Sharma, B. Water pollution with special reference to pesticide contamination in India. J. Water Resour. Prot. 02, 432-448. https://doi.org/10.4236/jwarp.2010.25050 (2010).

4. 4A, I. A. et al. In Water Challenges of an Urbanizing World Ch. Chapter 3, (2018). 
5. Cooper, C. M. Biological effects of agriculturally derived surface water pollutants on aquatic systems-A review. J. Environ. Qual. 22, 402-408. https://doi.org/10.2134/jeq1993.00472425002200030003x (1993).

6. Kant, R. Textile dyeing industry an environmental hazard. Nat. Sci. 04, 22-26. https://doi.org/10.4236/ns.2012.41004 (2012).

7. Ayed, L., Mahdhi, A., Cheref, A. \& Bakhrouf, A. Decolorization and degradation of azo dye Methyl Red by an isolated Sphingomonas paucimobilis: Biotoxicity and metabolites characterization. Desalination 274, 272-277. https://doi.org/10.1016/j.desal.2011.02.024 (2011).

8. Dawood, S. \& Sen, T. K. Removal of anionic dye Congo red from aqueous solution by raw pine and acid-treated pine cone powder as adsorbent: Equilibrium, thermodynamic, kinetics, mechanism and process design. Water Res. 46, 1933-1946. https://doi. org/10.1016/j.watres.2012.01.009 (2012).

9. Ibrahim, N. A., Hashem, A. \& Abou-Shosha, M. H. Animation of wood sawdust for removing anionic dyes from aqueous solutions. Polym. Plast. Technol. Eng. 36, 963-971. https://doi.org/10.1080/03602559708000673 (1997).

10. McMullan, G. et al. Microbial decolourisation and degradation of textile dyes. Appl. Microbiol. Biotechnol. 56, 81-87. https://doi. org/10.1007/s002530000587 (2001).

11. Pielesz, A. The process of the reduction of azo dyes used in dyeing textiles on the basis of infrared spectroscopy analysis. J. Mol. Struct. 511-512, 337-344. https://doi.org/10.1016/s0022-2860(99)00176-3 (1999).

12. Christie, R. M. Pigments, dyes and fluorescent brightening agents for plastics: An overview. Polym. Int. 34, 351-361. https://doi. org/10.1002/pi.1994.210340401 (1994).

13. Rekaby, M., Salem, A. A. \& Nassar, S. H. Eco-friendly printing of natural fabrics using natural dyes from alkanet and rhubarb. J. Text. Inst. 100, 486-495. https://doi.org/10.1080/00405000801962177 (2009).

14. Raval, N. P., Shah, P. U. \& Shah, N. K. Adsorptive amputation of hazardous azo dye Congo red from wastewater: A critical review. Environ. Sci. Pollut. Res. 23, 14810-14853. https://doi.org/10.1007/s11356-016-6970-0 (2016).

15. Frid, P., Anisimov, S. V. \& Popovic, N. Congo red and protein aggregation in neurodegenerative diseases. Brain Res. Rev. 53, 135-160. https://doi.org/10.1016/j.brainresrev.2006.08.001 (2007).

16. Reid, T. M., Morton, K. C., Wang, C. Y. \& King, C. M. Conversion of Congo red and 2-azoxyfluorene to mutagens following in vitro reduction by whole-cell rat cecal bacteria. Mutat. Res. Genet. Toxicol. 117, 105-112. https://doi.org/10.1016/0165-1218(83)90157 -x (1983).

17. Afkhami, A. \& Moosavi, R. Adsorptive removal of Congo red, a carcinogenic textile dye, from aqueous solutions by maghemite nanoparticles. J. Hazard. Mater. 174, 398-403. https://doi.org/10.1016/j.jhazmat.2009.09.066 (2010).

18. Mall, I. D., Srivastava, V. C., Kumar, G. V. A. \& Mishra, I. M. Characterization and utilization of mesoporous fertilizer plant waste carbon for adsorptive removal of dyes from aqueous solution. Colloids Surf. A 278, 175-187. https://doi.org/10.1016/j.colsu rfa.2005.12.017 (2006)

19. Han, R., Zhang, J., Zou, W., Shi, J. \& Liu, H. Equilibrium biosorption isotherm for lead ion on chaff. J. Hazard. Mater. 125, $266-271$. https://doi.org/10.1016/j.jhazmat.2005.05.031 (2005).

20. Ho, Y.-S., Chiu, W.-T. \& Wang, C.-C. Regression analysis for the sorption isotherms of basic dyes on sugarcane dust. Biores. Technol. 96, 1285-1291. https://doi.org/10.1016/j.biortech.2004.10.021 (2005).

21. Gupta, V. K., Ali, I., Suhas, \& Mohan, D. Equilibrium uptake and sorption dynamics for the removal of a basic dye (basic red) using low-cost adsorbents. J. Colloid Interface Sci. 265, 257-264. https://doi.org/10.1016/s0021-9797(03)00467-3 (2003).

22. Malana, M. A., Ijaz, S. \& Ashiq, M. N. Removal of various dyes from aqueous media onto polymeric gels by adsorption process: Their kinetics and thermodynamics. Desalination 263, 249-257. https://doi.org/10.1016/j.desal.2010.06.066 (2010).

23. Van Tran, T. et al. Facile synthesis of manganese oxide-embedded mesoporous carbons and their adsorbability towards methylene blue. Chemosphere 227, 455-461. https://doi.org/10.1016/j.chemosphere.2019.04.079 (2019).

24. Tran, T. V. et al. MIL-53 (Fe) derived magnetic porous carbon as a robust adsorbent for the removal of phenolic compounds under the optimized conditions. J. Environ. Chem. Eng. https://doi.org/10.1016/j.jece.2019.102902 (2020).

25. Tran, T. V. et al. High performance of Mn2(BDC)2(DMF)2-derived MnO@C nanocomposite as superior remediator for a series of emergent antibiotics. J. Mol. Liquids https://doi.org/10.1016/j.molliq.2020.113038 (2020).

26. Sud, D., Mahajan, G. \& Kaur, M. Agricultural waste material as potential adsorbent for sequestering heavy metal ions from aqueous solutions-A review. Biores. Technol. 99, 6017-6027. https://doi.org/10.1016/j.biortech.2007.11.064 (2008).

27. Chowdhury, A. N., Jesmeen, S. R. \& Hossain, M. M. Removal of dyes from water by conducting polymeric adsorbent. Polym. Adv. Technol. 15, 633-638. https://doi.org/10.1002/pat.521 (2004).

28. Nasar, A. \& Mashkoor, F. Application of polyaniline-based adsorbents for dye removal from water and wastewater-A review. Environ. Sci. Pollut. Res. 26, 5333-5356. https://doi.org/10.1007/s11356-018-3990-y (2019).

29. Ayari, F., Srasra, E. \& Trabelsi-Ayadi, M. Characterization of bentonitic clays and their use as adsorbent. Desalination 185, 391-397. https://doi.org/10.1016/j.desal.2005.04.046 (2005).

30. Sabarish, R. \& Unnikrishnan, G. Polyvinyl alcohol/carboxymethyl cellulose/ZSM-5 zeolite biocomposite membranes for dye adsorption applications. Carbohydr. Polym. 199, 129-140. https://doi.org/10.1016/j.carbpol.2018.06.123 (2018).

31. Messaoudi, N. E. et al. Evaluation of performance of chemically treated date stones: Application for the removal of cationic dyes from aqueous solutions. J. Taiwan Inst. Chem. Eng. 67, 244-253. https://doi.org/10.1016/j.jtice.2016.07.024 (2016).

32. Chowdhury, A. K., Sarkar, A. D. \& Bandyopadhyay, A. Rice husk ash as a low cost adsorbent for the removal of methylene blue and Congo red in aqueous phases. Clean Soil Air Water 37, 581-591. https://doi.org/10.1002/clen.200900051 (2009).

33. Sivaraj, R., Namasivayam, C. \& Kadirvelu, K. Orange peel as an adsorbent in the removal of Acid violet 17 (acid dye) from aqueous solutions. Waste Manag. 21, 105-110. https://doi.org/10.1016/s0956-053x(00)00076-3 (2001).

34. Giwa, A., Ahmed, M. \& Hasan, S. W. In Polymeric Materials for Clean Water Springer Series on Polymer and Composite Materials Ch. Chapter 8, 167-190 (2019).

35. Pandey, N., Shukla, S. K. \& Singh, N. B. Water purification by polymer nanocomposites: An overview. Nanocomposites 3, 47-66. https://doi.org/10.1080/20550324.2017.1329983 (2017)

36. Lee, A., Elam, J. W. \& Darling, S. B. Membrane materials for water purification: Design, development, and application. Environ. Sci. Water Res. Technol. 2, 17-42. https://doi.org/10.1039/c5ew00159e (2016).

37. Gonte, R. R., Shelar, G. \& Balasubramanian, K. Polymer-agro-waste composites for removal of Congo red dye from wastewater: Adsorption isotherms and kinetics. Desalin. Water Treat. 52, 7797-7811. https://doi.org/10.1080/19443994.2013.833876 (2013).

38. Hou, H., Zhou, R., Wu, P. \& Wu, L. Removal of Congo red dye from aqueous solution with hydroxyapatite/chitosan composite. Chem. Eng. J. 211-212, 336-342. https://doi.org/10.1016/j.cej.2012.09.100 (2012).

39. Khumalo, N. P. et al. Dual-functional ultrafiltration nano-enabled PSf/PVA membrane for the removal of Congo red dye. J. Water Process Eng. https://doi.org/10.1016/j.jwpe.2019.100878 (2019).

40. Mahmoodi, N. M. \& Mokhtari-Shourijeh, Z. Preparation of PVA-chitosan blend nanofiber and its dye removal ability from colored wastewater. Fibers Polym. 16, 1861-1869. https://doi.org/10.1007/s12221-015-5371-1 (2015).

41. Hu, T. et al. Facile preparation of tannic acid-poly(vinyl alcohol)/sodium alginate hydrogel beads for methylene blue removal from simulated solution. ACS Omega 3, 7523-7531. https://doi.org/10.1021/acsomega.8b00577 (2018).

42. Kloster, G. A., Mosiewicki, M. A. \& Marcovich, N. E. Chitosan/iron oxide nanocomposite films: Effect of the composition and preparation methods on the adsorption of Congo red. Carbohydr. Polym. 221, 186-194. https://doi.org/10.1016/j.carbpol.2019.05.089 (2019). 
43. Habiba, U. et al. Synthesis of chitosan/polyvinyl alcohol/zeolite composite for removal of methyl orange, Congo red and chromium(VI) by flocculation/adsorption. Carbohydr. Polym. 157, 1568-1576. https://doi.org/10.1016/j.carbpol.2016.11.037 (2017).

44. Zhao, Y. et al. Removal of dyes and $\mathrm{Cd}^{2+}$ in water by kaolin/calcium alginate filtration membrane. Coatings https://doi.org/10.3390/ coatings 9040218 (2019).

45. Zhang, Q., Xie, M., Guo, X., Zeng, L. \& Luo, J. Fabrication and adsorption behavior for Congo red of chitosan and alginate sponge. Integr. Ferroelectr. 151, 61-75. https://doi.org/10.1080/10584587.2014.899458 (2014).

46. Sabarish, R. \& Unnikrishnan, G. Synthesis, characterization and evaluations of micro/mesoporous ZSM-5 zeolite using starch as bio template. SN Appl. Sci. https://doi.org/10.1007/s42452-019-1036-9 (2019).

47. Mirqasemi, M. S., Homayoonfal, M. \& Rezakazemi, M. Zeolitic imidazolate framework membranes for gas and water purification. Environ. Chem. Lett. 18, 1-52. https://doi.org/10.1007/s10311-019-00933-6 (2019).

48. Wang, S., Li, H., Xie, S., Liu, S. \& Xu, L. Physical and chemical regeneration of zeolitic adsorbents for dye removal in wastewater treatment. Chemosphere 65, 82-87. https://doi.org/10.1016/j.chemosphere.2006.02.043 (2006).

49. Shaban, M., Abukhadra, M. R., Shahien, M. G. \& Ibrahim, S. S. Novel bentonite/zeolite-NaP composite efficiently removes methylene blue and Congo red dyes. Environ. Chem. Lett. 16, 275-280. https://doi.org/10.1007/s10311-017-0658-7 (2017).

50. Yin, C., Wei, Y., Wang, F. \& Chen, Y. Introduction of mesopority in zeolite ZSM-5 using resin as templates. Mater. Lett. 98, 194-196. https://doi.org/10.1016/j.matlet.2013.02.017 (2013).

51. Wang, Y., Yokoi, T., Namba, S. \& Tatsumi, T. Effects of dealumination and desilication of beta zeolite on catalytic performance in $n$-hexane cracking. Catalysts https://doi.org/10.3390/catal6010008 (2016).

52. Verboekend, D. \& Pérez-Ramírez, J. Design of hierarchical zeolite catalysts by desilication. Catal. Sci. Technol. https://doi. org/10.1039/clcy00150g (2011).

53. Ulusoy, U. \& Simsek, S. Lead removal by polyacrylamide-bentonite and zeolite composites: Effect of phytic acid immobilization. J. Hazard. Mater. 127, 163-171. https://doi.org/10.1016/j.jhazmat.2005.06.036 (2005).

54. Sabarish, R. \& Unnikrishnan, G. PVA/PDADMAC/ZSM-5 zeolite hybrid matrix membranes for dye adsorption: Fabrication, characterization, adsorption, kinetics and antimicrobial properties. J. Environ. Chem. Eng. 6, 3860-3873. https://doi.org/10.1016/j. jece.2018.05.026 (2018).

55. Sabarish, R. \& Unnikrishnan, G. Synthesis, characterization and catalytic activity of hierarchical ZSM- 5 templated by carboxymethyl cellulose. Powder Technol. 320, 412-419. https://doi.org/10.1016/j.powtec.2017.07.041 (2017).

56. Sabarish, R. \& Unnikrishnan, G. A novel anionic surfactant as template for the development of hierarchical ZSM-5 zeolite and its catalytic performance. J. Porous Mater. 27, 691-700. https://doi.org/10.1007/s10934-019-00852-5 (2020).

57. Darbasizadeh, B. et al. Crosslinked-polyvinyl alcohol-carboxymethyl cellulose/ZnO nanocomposite fibrous mats containing erythromycin (PVA-CMC/ZnO-EM): Fabrication, characterization and in-vitro release and anti-bacterial properties. Int. J. Biol. Macromol. 141, 1137-1146. https://doi.org/10.1016/j.ijbiomac.2019.09.060 (2019).

58. Adeli, H., Khorasani, M. T. \& Parvazinia, M. Wound dressing based on electrospun PVA/chitosan/starch nanofibrous mats: Fabrication, antibacterial and cytocompatibility evaluation and in vitro healing assay. Int. J. Biol. Macromol. 122, 238-254. https:// doi.org/10.1016/j.ijbiomac.2018.10.115 (2019).

59. Lavanya, C., Soontarapa, K., Jyothi, M. S. \& Geetha Balakrishna, R. Environmental friendly and cost effective caramel for Congo red removal, high flux, and fouling resistance of polysulfone membranes. Sep. Purif. Technol. 211, 348-358. https://doi.org/10.1016/j. seppur.2018.10.006 (2019).

60. Sundarrajan, P., Eswaran, P., Marimuthu, A., Subhadra, L. B. \& Kannaiyan, P. One pot synthesis and characterization of alginate stabilized semiconductor nanoparticles. Bull. Korean Chem. Soc. 33, 3218-3224. https://doi.org/10.5012/bkcs.2012.33.10.3218 (2012).

61. Aziz, S., Abdulwahid, R., Rasheed, M., Abdullah, O. \& Ahmed, H. Polymer blending as a novel approach for tuning the SPR peaks of silver nanoparticles. Polymers https://doi.org/10.3390/polym9100486 (2017).

62. Kittur, A. A., Kariduraganavar, M. Y., Toti, U. S., Ramesh, K. \& Aminabhavi, T. M. Pervaporation separation of water-isopropanol mixtures using ZSM-5 zeolite incorporated poly(vinyl alcohol) membranes. J. Appl. Polym. Sci. 90, 2441-2448. https://doi. org/10.1002/app.12930 (2003).

63. Isawi, H. Using zeolite/polyvinyl alcohol/sodium alginate nanocomposite beads for removal of some heavy metals from wastewater. Arab. J. Chem. 13, 5691-5716. https://doi.org/10.1016/j.arabjc.2020.04.009 (2020).

64. Tabatabaeefar, A., Keshtkar, A. R., Talebi, M. \& Abolghasemi, H. Polyvinyl alcohol/alginate/zeolite nanohybrid for removal of metals. Chem. Eng. Technol. 43, 343-354. https://doi.org/10.1002/ceat.201900231 (2020).

65. Kurşun, F. Application of PVA-b-NaY zeolite mixture membranes in pervaporation method. J. Mol. Struct. https://doi.org/10.1016/j. molstruc.2019.127170 (2020).

66. Prince, J. A. et al. Preparation and characterization of highly hydrophobic poly(vinylidene fluoride)—Clay nanocomposite nanofiber membranes (PVDF-clay NNMs) for desalination using direct contact membrane distillation. J. Membr. Sci. 397-398, 80-86. https ://doi.org/10.1016/j.memsci.2012.01.012 (2012).

67. Teli, S. B., Calle, M. \& Li, N. Poly(vinyl alcohol)-H-ZSM-5 zeolite mixed matrix membranes for pervaporation separation of methanol-benzene mixture. J. Membr. Sci. 371, 171-178. https://doi.org/10.1016/j.memsci.2011.01.033 (2011).

68. Wang, Y., Han, Q., Zhou, Q., Du, X. \& Xue, L. Molecular sieving effect of zeolites on the properties of PVA based composite membranes for total heat recovery in ventilation systems. RSC Adv. 6, 66767-66773. https://doi.org/10.1039/c6ra09725a (2016).

69. Suresh Kumar, B. V. et al. Effect of zeolite particulate filler on the properties of polyurethane composites. J. Polym. Res. 17, 135-142. https://doi.org/10.1007/s10965-009-9299-2 (2009).

70. Selim, A. et al. Preparation and characterization of PVA/GA/Laponite membranes to enhance pervaporation desalination performance. Sep. Purif. Technol. 221, 201-210. https://doi.org/10.1016/j.seppur.2019.03.084 (2019).

71. Prasad, C. V. et al. Preparation and characterization of 4A zeolite-filled mixed matrix membranes for pervaporation dehydration of isopropyl alcohol. J. Appl. Polym. Sci. 121, 1521-1529. https://doi.org/10.1002/app.33688 (2011).

72. Habiba, U., Lee, J. J. L., Joo, T. C., Ang, B. C. \& Afifi, A. M. Degradation of methyl orange and congo red by using chitosan/ polyvinyl alcohol/ $\mathrm{TiO}_{2}$ electrospun nanofibrous membrane. Int. J. Biol. Macromol. 131, 821-827. https://doi.org/10.1016/j.ijbio mac.2019.03.132 (2019).

73. Aysan, H., Edebali, S., Ozdemir, C. \& Celik Karakaya, M. \& Karakaya, N. Use of chabazite, a naturally abundant zeolite, for the investigation of the adsorption kinetics and mechanism of methylene blue dye. Microporous and Mesoporous Mater. 235, 78-86. https://doi.org/10.1016/j.micromeso.2016.08.007 (2016).

74. Brião, G. V., Jahn, S. L., Foletto, E. L. \& Dotto, G. L. Adsorption of crystal violet dye onto a mesoporous ZSM-5 zeolite synthetized using chitin as template. J. Colloid Interface Sci. 508, 313-322. https://doi.org/10.1016/j.jcis.2017.08.070 (2017).

75. Cheng, Z.-L., Li, Y.-X. \& Liu, Z. Fabrication of graphene oxide/silicalite-1 composites with hierarchical porous structure and investigation on their adsorption performance for rhodamine B. J. Ind. Eng. Chem. 55, 234-243. https://doi.org/10.1016/j.jiec.2017.06.054 (2017).

76. Baheri, B., Ghahremani, R., Peydayesh, M., Shahverdi, M. \& Mohammadi, T. Dye removal using 4A-zeolite/polyvinyl alcohol mixed matrix membrane adsorbents: Preparation, characterization, adsorption, kinetics, and thermodynamics. Res. Chem. Intermed. 42, 5309-5328. https://doi.org/10.1007/s11164-015-2362-1 (2015). 
77. Idan, I. J., Abdullah, L. C., Choong, T. S. Y. \& Jamil, S. N. A. B. M. Equilibrium, kinetics and thermodynamic adsorption studies of acid dyes on adsorbent developed from kenaf core fiber. Adsorpt. Sci. Technol. 36, 694-712. https://doi.org/10.1177/0263617417 715532 (2017)

78. Ma, Y. et al. Gelatin/alginate composite nanofiber membranes for effective and even adsorption of cationic dyes. Compos. B Eng. 162, 671-677. https://doi.org/10.1016/j.compositesb.2019.01.048 (2019).

79. Chen, W., Ma, H. \& Xing, B. Electrospinning of multifunctional cellulose acetate membrane and its adsorption properties for ionic dyes. Int. J. Biol. Macromol. 158, 1342-1351. https://doi.org/10.1016/j.ijbiomac.2020.04.249 (2020).

80. Litefti, K., Freire, M. S., Stitou, M. \& González-Álvarez, J. Adsorption of an anionic dye (Congo red) from aqueous solutions by pine bark. Sci. Rep. https://doi.org/10.1038/s41598-019-53046-z (2019).

81. Chatterjee, S., Lee, D. S., Lee, M. W. \& Woo, S. H. Congo red adsorption from aqueous solutions by using chitosan hydrogel beads impregnated with nonionic or anionic surfactant. Biores. Technol. 100, 3862-3868. https://doi.org/10.1016/j.biortech.2009.03.023 (2009).

82. Liu, C. et al. Graphene oxide reinforced alginate/pva double network hydrogels for efficient dye removal. Polymers https://doi. org/10.3390/polym10080835 (2018).

83. Zhang, B. et al. Adsorption of anion polyacrylamide from aqueous solution by polytetrafluoroethylene (PTFE) membrane as an adsorbent: Kinetic and isotherm studies. J. Colloid Interface Sci. 544, 303-311. https://doi.org/10.1016/j.jcis.2019.03.008 (2019).

84. Thiagamani, S. M. K., Krishnasamy, S. \& Siengchin, S. Challenges of biodegradable polymers: An environmental perspective. Appl. Sci. Eng Progress 12, 149 (2019).

\title{
Acknowledgements
}

Authors gratefully thanks the Centre of Innovation in Design and Engineering for Manufacturing (CoI- DEM), KMUTNB, Thailand for characterization facilities to carry out this study. The study was financially supported by the King Mongkut's University of Technology North Bangkok (KMUTNB), Thailand through the Post-Doctoral Program (Grant No. KMUTNB-62-Post-02, KMUTNB-63-Post-01 to SR) and (Grant No. KMUTNB-64KNOW-001, KMUTNB-BasicR-64-16).

\section{Author contributions}

S.R. (A)- Experimental work, Methodogy, Investigation and wrote main manuscript. JKk.(B)- prepared Figures and Tables. J.P. (C)- Review the manuscript. S.S. (D)-Supervision, reviewing and funding.

\section{Competing interests}

The authors declare no competing interests.

\section{Additional information}

Supplementary information is available for this paper at https://doi.org/10.1038/s41598-020-72398-5.

Correspondence and requests for materials should be addressed to S.R. or S.S.

Reprints and permissions information is available at www.nature.com/reprints.

Publisher's note Springer Nature remains neutral with regard to jurisdictional claims in published maps and institutional affiliations.

\begin{abstract}
Open Access This article is licensed under a Creative Commons Attribution 4.0 International License, which permits use, sharing, adaptation, distribution and reproduction in any medium or format, as long as you give appropriate credit to the original author(s) and the source, provide a link to the Creative Commons licence, and indicate if changes were made. The images or other third party material in this article are included in the article's Creative Commons licence, unless indicated otherwise in a credit line to the material. If material is not included in the article's Creative Commons licence and your intended use is not permitted by statutory regulation or exceeds the permitted use, you will need to obtain permission directly from the copyright holder. To view a copy of this licence, visit http://creativecommons.org/licenses/by/4.0/.
\end{abstract}

(C) The Author(s) 2020 